\title{
The Correlation among Students' Reading Interest, Reading Comprehension, and Their Intralingual Translation Achievement
}

\author{
Despita \\ STIA Satya Negara Palembang \\ Email: despita.kurniawan@gmail.com
}

\begin{abstract}
Enthusiasm support a vital role in reading comprehension achievement of upper level readers, Reading interest is vital that one may encourage and maintain their interest of reading. Intralingual translation is defined as "rewording" and as an interpretation of verbal signs by means of other signs of the same language. This research is a quantitative research which has the purpose to find out whether or not there was significant correlation among students' reading interest, reading comprehension, and their intralingual translation achievement. Furthermore, the population of the research is the second semester students of STIA SATYA NEGARA Palembang consisting of 120 students, from the population, 42 students were represented as the sample which was taken through simple random sampling technique. The instruments used were questionnaire for reading interest, multiple choice test for reading comprehension, and written test for intralingual translation. After having the result, then the data were analyzed by using multiple correlation in SPSS 20 Program for Windows. From the result of the data analysis shows that Ryx $1 \times 2=0.655$ at the significance level of 0.05 , and for the criteria of significant test is gotten Fcount (37.037) > Ftable (4.08). So, the result of hypothesis test shows that there is significant correlation among students' reading interest, reading comprehension, and their intralingual translation achievement. It can be concluded that if students have high interest in reading, so they have good ability in comprehending text.
\end{abstract}

Keywords: Reading Interest, Reading Comprehension, Intralingual Translation Achievement

\section{Hubungan antara Minat Baca, Pemahaman Membaca dan Kemampuan Menerjemahkan Secara Intralingual}

\begin{abstract}
Abstrak
Minat berperan penting dalam pencapaian pemahaman membaca pembaca, minat membaca sangat penting untuk mendorong dan mempertahankan minat membaca mereka. intralingual didefinisikan sebagai "penulisan ulang" dan sebagai eksplanasi rambu-rambu verbal dengan memakai rambu-rambu lain dari bahasa yang sama. Penelitian ini adalah penelitian kuantitatif yang memiliki tujuan untuk melihat apakah ada kedekatan yang berkaitan antara keinginan baca siswa atau tidak, pemahaman membaca, dan prestasi terjemahan intralingual mereka. Selanjutnya, populasi penelitian ini adalah siswa semester dua STIA SATYA NEGARA Palembang yang terdiri dari 120 siswa, dari populasi, 42 siswa diwakili sebagai sampel yang dipakai melalui cara contoh acak sederhana. Alat yang dipakai adalah angket untuk minat baca, tes pilihan ganda
\end{abstract}


untuk pemahaman membaca, dan tes tertulis untuk terjemahan intralingual. Setelah mendapatkan hasilnya, maka data dianalisis dengan menggunakan korelasi ganda dalam Program SPSS 20 untuk Windows. Dari hasil analisis data menunjukkan bahwa Ryx1x2 = 0,655 pada taraf signifikansi 0,05, dan untuk kriteria uji signifikan diperoleh $F$ hitung (37,037)> Ftabel (4,08). Jadi, hasil uji asumsi memperlihatkan bahwa ada keterkaitan yang relevan antara keinginan membaca siswa, pemahaman membaca, dan prestasi terjemahan intralingual mereka. Dapat disimpulkan bahwa bila siswa mempunyai keinginan membaca yang tinggi, maka mereka memiliki kemampuan yang baik dalam memahami teks.

Kata kunci: Minat Baca, Pemahaman Membaca, dan kemampuan menerjemahkan secara Intralingual

\section{INTRODUCTION}

The standard definitions of "translation" commonly refer to transfer processes from one language into another or to the end product of such a transfer. However, translation is not only an interlingual and intercultural phenomenon. Translation also occurs within the "same" linguistic and cultural domain. One example of intralingual translation or paraphrase is the numerous varieties of expert-tolayperson communication where the sophisticated language of the text needs to be simplified for the layperson. Translation as the updating of archaic or older texts, modernization or cross-cultural adaptation of children's literature, replacing cultural words between different varieties of the same language, and rewritings within a postcolonial context are also types of intralingual translation. Moreover, narratives ranging from folktales, legends, and myths to some foundational texts are handed down from generation to generation through the process of oral-to-oral intralingual translation before being written down, that is, translated intralingually or paraphrase.

According to Veit, Gould, and Clifford (in Icha:24),"paraphrase is an expression of the meaning of a word or phrase using other words orphrases, often in an attempt to make the meaning easier to understand."For example, to make (someone or something) appear or feel younger isa paraphrase of the English verb rejuvenate. Dictionary definitions oftentake the form of paraphrases of the words they are trying to define.

When the students paraphrase a statement or a piece of writing,they recast its ideas in different words. The purpose of their note was to clarify the statement, to restate and perhaps simplify the author's idea in their own writing.

When the students write for others to read, they are attached by defenite limitations of action show. specifically, they must totally rearrage topic lent from their documens, with their own language and their own direction.

In one of the first formulations by Jakobson (in Hatim, 2012), intralingual translation is defined as "rewording" and as an interpretation of verbal signs by means of other signs of the same language. Intralingual translation is generally not visible, intralingual translation to explore the diverse practices and concepts of intralingual translation in different cultural and temporal settings. Just as is true with interlingual translation, intralingual translation too cannot be examined independent from its cultural, linguistic, and social context. In fact, when the language is the "same", the extra nonlinguistic aspects are more prominently exposed. Examining intralingual translations from a historical-descriptive viewpoint can reveal much about the target system to which 
they belong. In this research the researcher researched about students' intralingual translation achievement in translating English into English (intralingual translation/ paraphrasing), so English as a SL and English also as a TL.

Translation is an essential thing that should be mastered by students in order to achieve a sucessful learning process. Therefore, the students must have the knowledge about translation, The students' knowledge of the second semester students of STIA SATYA NEGARA Palembang about translation is still lack because they do not know how to translate in good English well and correctly.

According to Bell (in Despita 2018 :20), "Translation is very important when we are reading a text." Based on Bell's statement that translation is very important in teaching reading text and also translation has important role in understanding a text. If students cannot translating text, it will be a problem for students because there will be miss understanding between the translator and the reader.

Basically, in translating process students should masterthe content, vocabulary, and grammar, because both have important matter to be mastered. Vocabulary is very important to be mastered before they begin to translate because this component is very important to increase students' ability in paraphrasing or intralingual traslation a text.Translating English is not easy work. The translator should know the vocabulary that is appropriate with the text which is translated. Sometimes the students translate word by word without paying attention on the structure of sentence in English. Generally, students' problem in translating is not only from vocabulary factor, but also another factor, such as grammar. Grammar has big influence in translating, because if the translator does not arrange the sentences correctly and appropriately, it means that the translation result is bad and cannot be understood by the reader or listener.

According to Rutherford (in Purpura, 2014:1), "grammar is used to mean the analysis of a language system and the study of grammar is not just considered an essential feature of language learning, but it teaches to be sufficient for learners to acquire another language". Therefore, the understanding about grammar is very important in English.

Interest plays a vital role inreading comprehensionachievement of higher level readers. By determining individualstudents' interest in particular topics and creating reading comprehension, they can gethigh interest, to determine that the performance of higher ability readers are importantly influenced by their interest in the delivery content, the students cannot have middle or lower ability in reading interest. Reading interest is vital so encourage and confirm their interest of reading.

The researcher is interested in analizing it because of main point that can affect students' intralingual translation achievement. Comprehension is rate of the idea to notice and get the strength, act, and process of greedy with intellegence, insight, viewing as comprehension of abstract truth. Ability in comprehending a text is primarily crucial to be improved so that students can get the message, information and aim of a text in written form. If students have comprehended, they would have been able to translate the text well.

From the explanations above, the problems of translating are found by the second semester learners of STIA SATYA NEGARA Palembang. Furthermore, the population of the research is the second semester students of STIA SATYA NEGARA Palembang. Their score in translation is still low, it may be considered from the yield of learners' valuation at the first semester students of STIA SATYA 
NEGARA Palembang Furthermore, the population of the research is the second semester students of STIA SATYA NEGARA Palembang build upon the data that out of 120 students following the English translation material, only about 50 students who got score 70 to 100 . It means that only $41.7 \%$ students who could be categorized successful or got good score in English translation material.

Based on the preliminary research, there were several factors which make the students' scores in translation were low, the first factor was from the students themselves that is students' reading interest. The students were not interested in reading English books, such as scientific books, story books, magazines, or newspapers. They also felt lazy to read English books, they felt difficult to read English books, because they assumed that English was difficult.

The second factor was that the students had difficulty in comprehending the text.They just read the text without getting the point from the text, so they could not get the meaning of the text easily, and they felt difficult in getting ideas and message from the text. whereas, the students should comprehend a text first before they translate it. If the students had comprehended the text, they would have been easier to translate the text. So, it was improbable to the learners to translate a text without having reading interest and comprehending the text before.

Related to the previous description, the researcher was interested in conducting a research entitled: "The Correlation among Students' Reading Interest, Reading Comprehension, and Their Intralingual Translation Achievement of the second semester students of STIA SATYA NEGARA Palembang.

The researcher focused the research on the Correlation among Students' Reading
Interest, Reading Comprehension, and Their intralingual translation Achievement of the second semester students of STIA SATYA NEGARA Palembang.

The objectives of this study was to find out whether or not there are correlation among Students' Reading Interest, Reading Comprehension, and Their Intralingual Translation Achievement of the second semester students of STIA SATYA NEGARA Palembang.

\section{Concept of Intralingual Translation}

The basic definitions of "translation" as usual refer to removal ways by one language for another or to the close result of such a removal. Nevertheless, translation is not just an interlingual and intercultural symptom. According to Jakobson (in Hatim, 2015:1), "Translation also occurs within the "same" linguistic and cultural domain."

In one of the first formulations by Jakobson (in Hatim, 2015:19), intralingual translation is defined as "rewording" and as an interpretation of verbal signs by means of other signs of the same language. Intralingual translation is generally not visible, intralingual translation to explore the diverse practices and concepts of intralingual translation in different cultural and temporal settings. Just as is true with interlingual translation, intralingual translation too cannot be examined independent from its cultural, linguistic, and social context. In fact, when the language is the "same", the extra nonlinguistic aspects are more prominently exposed. Examining intralingual translations from a historical-descriptive viewpoint can reveal much about the target system to which they belong.

In this research the researcher researched about students' intralingual translation achievement in translating English into English (intralingual translation/paraphrasing), so English as a SL and English also as a TL or the other words 
isparaphrase. According to Veit, Gould, and Clifford in Despita :24),"paraphrase is an expression of the meaning of a word or phrase using other words orphrases, often in an attempt to make the meaning easier to understand."For example, to make (someone or something) appear or feel younger is a paraphrase of the English verb rejuvenate. Dictionary definitions oftentake the form of paraphrases of the words they are trying to define.

When the students paraphrase a statement or a piece of writing,they recast its ideas in different words. The purpose of their note was to clarify the statement, to restate and perhaps simplify the author's idea in their own writing.

When the students write for others to read, they are attached by defenite limitations of action show. specifically, they must totally rearrage topic lent from their documens, with their own language and their own direction.

Larson in Djuharie (2014:12) states that "Translation consists of studying the lexicon, grammatical structure, communication situation and cultural context of the source language, analyzing it in order to determine its meaning, then reconstructing the same meaning using the lexicon and grammatical structure which appropriate in the receiver language."

According to Newmark (2013:21) "there are two approaches to translating (1) start translating sentence by sentence, for say the first paragraph or chapter, to get the feel and the feeling tone of the text, and then deliberately sit back, review the position, and read the rest of the SL text; (2) read the whole text two or three times, and find the intention, register, tone, mark the difficult words and passages and start translating only when you have taken your bearings.

"As for the process of translation, it is often dangerous to translate more than a sentence or two before reading the first two or three paragraphs, unless a quick glance through convinces you that the text is going to present few problems" (Newmark, 2013:51).

Jakobson (in Hatim, 2012: 26) makes very necessary difference among three categorize of written translation:

1. Intralingual translation- translation within the same language, which can involve rewording or paraphrase;

2. Interlingual translation - translation from one language to another, and

3. Intersemiotic translation - translation of the verbal sign by a non-verbal sign,

In translating, we should know the process of translation before we start to translate. Nababan (in Despita 2018:24) states that "Process of translation is an activity system in translation activity." $\mathrm{He}$ also divides process of translation into three major steps. They are:

1. Analyzing the Source Language (SL) The first step is analyzing the text. We analyze the text by first reading the Source Language (SL) and gain the meaning in the text. We also analyze the linguistics and exstralinguistics elements in the text. Linguistics elements is the elements deals with language, while extralinguitics is the elements beyond the language, such as the culture and the social context of the text. In analyzing the linguistics elements, we analyze the text at all level such as in the level of sentence, clause, phrase, and word. By doing this, we can gain the fully understanding of the meaning in the Source Language (SL).

2. Transferring the Message

The second step is transferring the message. In this step the translator has to find the equivalent of the Source language (SL). This process happens in mind (Nababan called it as proses 
batin). It means that this process is in the abstract form.

\section{Restructuring}

The last step is restructuring. In this step is also called as the finishing touch when the interpreter attemps to rewrite the origin speech text into goal speech text. It means, to get better translation result the translator should arrange the structure or grammar of the source language text which have been translated before become an appropriate language style to the goal speech text.

In translating a text, there are some influencing factors of translation. According to Rokhman in Despita (2018:11), in translating a text, there are factors that influence the translation process that include contextual, textual, and translator factor. This factor is related with the text production context that include language history, text writer, the culture text places is producted, the region text place is producted, text social variation, and topic of text. This element can be called contextual factor. Then, textual factor is formed by elements likes; word, phrase, clause, sentence, punctuation, and grammatical text. The last factor is translator. Translating process can not be separated from the element of translator itself. This condition is affected by some factors such as: competency of the translator, their perception, and the instrument which is used by them in translating process.

There are several kinds of translation method, as proposed by Newmark in Djuharie (2014:18) "They are word for word, literal translation, loyal translation, semantic translation, adaptation, free translation, idiomatic translation and communicative translation".

a. Word for word

It is often demonstrated as interlinear translation. The word-order is preserved and the words translated one by one by their most common meanings, without considering context. Cultural words are translated literally. The main use of word-for-word translation is either to understand the arranging of the source language or to construe a difficult text as a pre-translation process.

b. Literal Translation

In this translation, the grammatical constructions are changed to their nearest with source language but the lexical words are translated one by one without considering context. As a pre-translation process, this indicates the problems to be solved.

c. Loyal Translation

A loyal translation tries to reproduce the precise contextual meaning with the original texts within the constraints of the SL grammaticalstructures. It cultural words 'transferred' and the degree of 'abnormality' the grammatical and lexical are preserves. Translation is attempts to be fully loyal to the intention and the text-realization from Source Language.

d. Semantic Translation

Semantic translation differs from 'loyal translation' because it must take more account of the aesthetic value of the Source Language (SL). In this translation, cultural words are not be translated with cultural terms but it uses functional terms or culturally neutral.

\section{e. Adaptation}

This is the 'freest' form of translation. It is used mainly for plays (comedies) and poetry; the themes, characters, plots are usually preserved, but the Source Language cultural is changed to the Target Language cultural and the text rewritten.

\section{f. Free Translation}

Free translation reproduces the matter without the manner, or the contentwithout the form of the original. This translation is usually a paraphrase which longer than the original material, a so-called 'intralingual translation', often prolix and pretentious, and not translation at all. 
g. Idiomatic Translation

Idiomatic translation reproduces the 'message' of the original but tends to distort nuances of meaning by preferring colloquialisms and idioms where these do not exist in the original.

h. Communicative Translation

Communicative translation attempts to render the exact contextual meaning from source language and content or language are easy to be received. Then, it can be understood by the reader.

Based on explanation above, there is one line of similarity that is translation process consists of three parts; word by word, literal, and free. Translation process above is useful to produce the precise understanding of meaning so that translation result has the similarity of message, impression, nuance, and context. Translation always begins from understanding word by word and followed by meaning of word in analyzing of grammatical.

According to Mulyasa (2014:39), interest is "The tendencies of human being in doing the action. For example, the willing of students in learning some lessons and the willing of students in mastering learning material. Meanwhile, Sukardi in Hidayat (2014:114) says that "Interest is a mental equipment which contains of the combination of feel, expectation. Speculation doubt, and other tendencies which can affect someone or internal to do something.

Ebbers (2012:1) has the same definition which says "Interest is described as a motivational force that involves the focused allocation of extra affection, leading to deeper processing, better comprehension, longer recall." Interest can be influenced to point motivating contrain that leads person to give concern to a person, a thing, or an activity. Interest is freely choosing activity, which holds the attention and is a source of satisfaction and pleasure. Interest refers to motivating force which causes individual to give attention to a person, a thing or an activity, interest is closely related to attention, motivation and pleasure. Activity which is followed by intensive attention will be more succeed, so the achievement is higher.

From the theories above it can be concluded that because of interest to lesson which is learned, students will be happy and easy to do the task of the lesson. Therefore, it can be said that pleasure feeling to English lesson motivate to do the positive attitude and finally it makes interested to English. Because of interest, students will be easier to understand English, so they will be successfully in learning English. Interest plays important role in all activities. It is the important factor that must be fulfilled before carrying out the activities. It can motivate someone to do them and to achieve the goal consciously. If one has a good interest, he or she will be likely to seek some books to be learned. Interest even points to a feel of attention with curiosity about somebody or something and the strenght of drawing or taking one's concern. In learning activity.interest determines one's success. Interest has a high important role in influencing learning activity which includes emotion, feeling, attention, satisfaction, motivationand pleasure. The personal positive interest and attitudes of each learner will increase the chance for success.

Fox (2010:28) mentions "two types of interest there are: personal and situational interest." Personal interest refers to evidence that is of lasting personal worth, activated internally, and topic-specific. Personal interest as well is pointed to as individual or line interest. The foundation of Personal interest arises to be pre-existing awareness, personal evens and affects. Fettle interest refers to evidence that is of temporary worth, surrounding activated, and context-specific. Evidence which is uncommon or involved inside a specific context falls to this group 


\section{Concept of Reading Comprehension}

Comprehension is very essential in reading process. Someone does not really read if he or she does not understand what is being read, even if he or she can pronounce the words perfectly. Reading can be challenging, particularly when the material is unfamiliar, technical, or complex. Moreover, for some readers, comprehension is always challenging. They may understand each word separately, but linking them together into meaningful ideas often doesn't happen as it should. These readers can decode the words, but have not developed sufficient skills to comprehend the underlying, deeper meaning of the sentences, the paragraphs, and the entire text. According to McNamara (2013:xi), "comprehension refers to the ability to go beyond the words, to understand the ideas and the relationships between ideas conveyed in a text". Reading is an extraordinary achievement when one considers the number of levels and components that must be mastered. Consider what it takes to read a simple story. The words contain graphemes, phonemes, and morphemes. Sentences have syntactic composition, propositions, and stylistic features.

Deep comprehension of the sentences requires the construction of referents of nouns, a discourse focus, presuppositions, and plausible inferences. The reader need to distinguish given versus new information in the text and implicitly acknowledge what is shared among most readers in a community (called the common ground). At more global levels, the reader needs to identifythe genre, rhetorical structure, plot, perspective of different characters, narrator, theme, story point, and sometimes the attitude of the author.

Richards, et al. (2010:11) state that "Reading comprehension is the primarily purpose for reading (though this is sometimes overlooked when students are asked to read overly difficult texts): raising student's awareness of main ideas in a text and exploring the organization of a text are essential for good comprehension."Ability in comprehending a text is primarily crucial to be improved so that students can get the message, information and aim of a text in form written. If students had comprehended, student would have been able to make a text which meaning and achieve the purpose of reading. The reader makes awereness, skills, and strategies to specify what the meaning is. Reader's awereness, ability, and strategies include linguistic capability, discourse competence, sociolinguistic competence. Comprehension refers to understanding, the ability to get the meaning of something. Comprehension is very essential in reading process. Someone does not really read if he or she does not understand what is being read, even if he or she can pronounce the words perfectly.

Hadley (2011:151) explains that "comprehension is an active process where students interact with the text, using background knowledge that they bring to the comprehension process as well as thelinguistics and rhetorical features of the text itself." The purpose for reading, guide the reader's selection of the texts. The goal for reading as well set the right approach to reading comprehension. Reading comprehension means comprehending or understanding new information and ideas presented in the printed page and utilizing them as the application of interaction between the reader and author.

Moreover, Kasihani (2015:65) states that "reading comprehension have a purpose to gain an information from the texts or the material which is read."'Therefore, the students have to practice to read with the purpose to gain the in Information about the content of the text. Reading comprehension outcome when the reader finds which skills and strategies are suitable for the type of text, 
and get how to occur them to complete the reading goal. Furthermore, Harris (2013:2) says that "reading comprehension is the process of constructing meaning by coordinating a number of complex processes that include word reading, word knowledge, and fluency." In line with Harris, Grellet in Hadley (2011:205) states that "reading comprehension means understanding a written text to extract the required information from it as efficiently as possible." Grellet emphasizes the importance of obtaining the required information in reading.

By the theories above, it may be deduced lest reading comprehension is grasping the text meaning, understand it according to experimental background or prior knowledge, and interpret it with the reader's needs and purposes.

Hadley (2011:161) adds that in the second language comprehension process, at least three types of background knowledge are potentially activated:

1. Linguistic information, or one's knowledge of the target language code.

2. Knowledge of the world, including one's store of concepts and expectations based on prior experience.

3. Knowledge of discourse structure, or the understanding of how various kinds or types of discourse (such as conversations, radio broadcast, literary texts, political speeches, newspaper and magazine stories, and the like) are generally organized. When language practice is limited to themanipulation or processing of linguistic form, only the first type of background knowledge is involved. By contrast, language learning activities that provide relevant context should be helpful in activating students' knowledge of the world and of familiar discourse structure.

In short, ability in comprehending a text is very important because without reading comprehension would be empty and meaningless. Comprehending text includes all of the processes related to derive meaning from written language like books, texts, article etc. Deriving meaning indicates that there is meaning in text and that meaning needs to be understood.

Reading comprehension is an understanding in reading so that get new information of the text which has been read. It means, reading comprehension is used to measure generally focus on the students' understanding of reading text.

\section{METHOD}

This research is quantitative research with correlational research design, because there are correlation of $\mathrm{X} 1, \mathrm{X} 2$ and $\mathrm{Y}$. Sugiyono (2012:7) states "quantitative research is research that the research data in the form of numeral and analysis used statistics."

This research has three variables that researched. Conforming to Arikunto (2010:159), "A variable is defined as something that varies from one case to another." The dependent variable is variable which one observes and measures to determine the effect of the independent variable. Independent variable (the major variable) is the variable which is selected manipulated and measured by the researcher. This research has two independent variables. They are reading interest as $\mathrm{X} 1$ and reading comprehension as $\mathrm{X} 2$, and the dependent variable is intralingual translation achievement as Y.

This research aimed to find out how much distribution of correlation between independent variable (X1) and dependent variable $(\mathrm{Y})$, independent variable $(\mathrm{X} 2)$ and dependent variable (Y), independent variable (X1) and independent variable (X2), and the correlation among independent variables (X1, X2) and dependent variable (Y). And this research answered the formulation of the problem, 
hypothesis test and concluded the correlation among reading interest (X1), reading comprehension (X2), andintralingual translation achievement (Y). According to Emzir (2012:45), "Pedictive study concerns if any significant influence of two independent variables toward dependent variable." It means that, independent variable and dependent variables are having close influence with each other. Variable which became base of making prediction called as predictor and variable which is predicted called as criteria.

The population in this study is the learners of the second semester learners of STIA SATYA NEGARA Palembang which be compused of 120 learners.

The sample in this research taken by using list of the students' name of three classes and then randomly selected their names by making small pieces of paper with the name of the subjects written on them and those papers are rolled and come into a tin. After that, the tin is mixed, and the paper is dropped out from the tin.

In this research, the data were collected by giving the tests and questionnaire to the students of the sixth semester. Moreover, in applying the test the researcher has a questionnaire for reading interest and tests for reading comprehension, and translation. The procedure of testing is that the researcher gave a test before conducting the research for learners that be composed of 25 grains questionnaire in reading interest, the technique of scoring the questionnaires that the researcher used was Linkert Scale Type, and 40 items multiple choice for reading comprehension and also essay form for translation. This research did in three meetings. The first meeting was about reading interest, second meeting was about reading comprehension and the last meeting was about translation test.

\section{FINDING AND DISCUSSION}

This reasearch has three types of data; they are students' reading interest, reading comprehension, and intralingual translation achievement.

To measure the students' reading interest, the researcher distributed questionnaire consisting 25 items in the form of Likert Scale.

To assess reading comprehension in this reasearch multiple choice test was used with four choices A, B, C, and D, with the total of items are 40. Students who answered right given score 1 , and 0 for wrong answer, the right answer multiplied by 2.5 , so the highest scoreis 100 and the lowest is 2.5

For the students' intralingual translation achievement, the researcher distributeda written test. Students had to translate the English text into good English (intralingual translation) by the following aspects: organization, content, grammar, mechanic, and style and quality of expression/vocabulary.

There are four hypotheses had to be tested in this research. They are (1) H0: there is no significant correlation between students' reading interest and their intralingual translation achievement and Ha: there is significant correlation between students' reading interest and their intralingual translation achievement, (2) H0: there is no significant correlation between students' reading comprehension and their intralingual translation achievement and $\mathrm{Ha}$ : there is significant correlation between students' reading comprehension and their intralingual translation achievement, (3) H0: there is no significant correlation between students' reading interest and reading comprehension and Ha: there is significant correlation between students' reading interest and reading comprehension, (4) $\mathrm{H} 0$ : there is no significant correlation among students' reading interest, reading comprehension, and their intralingual translation achievement and 
Ha: there is significant correlation among students' reading interest, reading comprehension, and their intralingual translation achievement.

To analyze the correlation among three variables above, multiple correlation (Ryx1x2) was used, and the analysis of their regression was used multiple linier regression formula in SPSS 20 Program for Windows.

The result of the correlation coefficient between students' reading interest and their intralingual translation achievement is $\operatorname{Ryx} 1=0.797$ with $\mathrm{r}^{2}=0.626$ (or $62.6 \%$ ) influenced of reading interest and $37.4 \%$ from other factors. It means that there is correlation between students' reading interest and translation achievement. the significant level was gotten Sig (0.000) $<\alpha(0.01)$, consequently, H0 is rejected. It means that between students' reading interest and their intralingual translation achievement have significant correlations.

The result of the correlation coefficient between students' reading comprehension and their intralingual translation achievement is $\operatorname{Ryx} 2=0.515$ with $\mathrm{r}^{2}=0.266$ (or 26.6\%) influenced of reading comprehension, and $73.4 \%$ from other factors. It means that there is significant correlation between students' reading comprehension and the intralingual translation achievement. And from the table above, the researcher got the significant level $\operatorname{Sig}(0.000)<\alpha(0.01)$, consequently, $\mathrm{HO}$ is rejected. It means that between students' reading comprehension and their translation achievement have significant correlations.

The result of the correlation coefficient between students' reading interest and reading comprehension is $\mathrm{Rx} 1 \times 2=0.492$ with $\mathrm{r}^{2}=0.242$ (or 24.2\%) influenced of reading interest and $75.8 \%$ from other factors. It aims that there is correlation between students' reading interest and reading comprehension.And the significant level that the researcher found was $\mathrm{Sig}$ $(0.001)<\alpha(0.01)$, consequently, $\mathrm{H} 0$ is rejected. It means that between students' reading interest and reading comprehensionhave significantcorrelations.

The result of the correlation coefficient among students' reading interest, reading comprehension, and their translation achievement, the researcher foundThe result of the correlation coefficient among students' reading interest, reading comprehension and their translation achievement is Ryx $1 \times 2=$ 0.809 with $\mathrm{r}^{2}=0.655$ (or $65.5 \%$ ) influenced of reading interest and reading comprehension and $34.5 \%$ from the other factor.It means that there is correlation among students' reading interest, reading comprehension, and their intralingual translation achievement. Form the table above, the researcher found that significance level of X1and Y is Sig (0.000) and X2, and $\mathrm{Y}$ is $\operatorname{Sig}(0.000)<\alpha(0.01)$, consequently, H0 is rejected. It means that students' reading interest, reading comprehension have significant correlation, and intralingual translation achievement.

\section{CONLUSION}

The following conclusion can be drawn as follows.

The first is the correlation between students' reading interest (X1) andtheir translation achievement $(\mathrm{Y})$ is $\mathrm{Ryx} 1=0.797$, consequently, there is correlation between $\mathrm{X} 1$ and $\mathrm{Y}$. The level of significant is Sig $(0.000)<\alpha(0.01)$, consequently, $\mathrm{H} 0$ is rejected. It means that between students' reading interest and their ability in intralingual translation achievement have high necessary correlation of the second semester students of STIA SATYA NEGARA Palembang. From the findings, it can be concluded that if students have high interest in reading English, so they can translate intralingually easily and well. 
The second is the correlation between students' reading comprehension (X2) andtheir translation achievement $(\mathrm{Y})$ is Ryx2 $=0.515$, consequently, there is correlation between $\mathrm{X} 2$ and $\mathrm{Y}$. The level of significant is Sig $(0.000)<\alpha(0.01)$, consequently, $\mathrm{H} 0$ is rejected. It means that between students' readingcomprehension and,their intralingual translation achievement have high significant correlations of the second semester students of STIA SATYA NEGARA Palembang.From the finding, it can be concluded that if students have good ability in comprehending text and they can comprehend it easily, therefore the ability of the students in translating intralingually text is also good, and they will get good achievement in translation.

The third is the correlation between students' reading interest (X1) and reading comprehension (X2) is $\mathrm{Rx} 1 \times 2=0.492$, consequently, there is correlation between $\mathrm{X} 1$ and $\mathrm{X} 2$. The level of significant is Sig $(0.001)<\alpha(0.01)$, consequently, $\mathrm{H} 0$ is rejected. It means that between students' reading interest and reading comprehension have high necessary correlation of the second semester students of STIA SATYA NEGARA Palembang. From the finding, it can be concluded that if students have high interest in reading, so the students' ability in comprehending the text is also good.

The fourth is the correlation among students' reading interest (X1), reading comprehension (X2), andtheir intralingual translation achievement $(\mathrm{Y})$ is $\mathrm{Ryx} 1 \times 2=$ 0.809 , consequently, there is correlation among X1, X2, and Y. Then between X1 andX2 give influence $65.5 \%$ toward $Y$. The significance level of $\mathrm{X}$ land $\mathrm{Y}$ has Sig $(0.000)$ and X2and $\mathrm{Y}$ has Sig (0.000) $<\alpha(0.01)$, consequently, $\mathrm{H} 0$ is rejected. It means that among students' reading interest, reading comprehension, and their intralingual translation achievement have high significant correlation of the second semester students of STIA SATYA NEGARA Palembang. It can be concluded that if students have high interest in reading, so they have good ability in comprehending text, of course they are able to comprehend it easily, therefore the ability of the students in translating intralingually text is also good, and they will get good achievement in translation.

\section{REFERENCES}

Arikunto, Suharsimi. 2010. Prosedur Penelitian Suatu Pendekatan Praktik Edisi Revisi. Jakarta: PT. Rineka Cipta.

Bell. T. Roger In Despita. 2018. An Analysis of Students' Ability Translation Narrative Text. Palembang: STIA Satya Negara.

Despita. 2018. An Analysis of Students' Ability Translation Narrative Text. Palembang: STIA Satya Negara.

Djuharie, O., Setiawan. 2014. Teknik dan Panduan Menerjemahkan. Bandung: Yrama Widia.

Ebbers, Susan M. 2012. How to Generate Interest of Reading Comprehension Improves. Accessed from Online Journal.http:/academic. Cuesta.Edu/acasupp/AS/501.Htm. on Sunday November 13, 2013.

Emzir. 2012. Metodologi Penelitian Pendidikan Kuantitatif dan Kualitatif. Jakarta: Rajawali Press.

Fox, Emily et al. 2010. Reading Interest and the Model of Learning:

A Development Model of Interest, Knowledge, and Strategy Use in TextComprehension.Accessedfromht tp://books.google.co.id/books?id==S 
xrteKv5qnwC\&printsec=frontcover \&hl=id. England: Maryland on Monday, December 20, 2013.

Hadley, Alice., Omaggio. 2011. Teaching English in Context. Boston, America :Thomas Higher Education.

Hatim, Basil. 2012. Translation an advanced resource book. London and New York: Routledge

Hidayat, Sholeh. 2014. Hubungan Minat Terhadap Profesi Guru dan Motivasi Berprestasi dengan Keterampilan Mengajar. Jurnal Pendidikan dan Kebudayaan No. 075 Tahun ke 14.

Kasihani, K. E., Suyanto. 2015. English for Young Learners. Yogyakarta: PT. BumiAksara.

McNamara, Danuelle S. 2013. Reading Comprehension Strategies. New York: Lawrence Erlbaum Associate.

Mulyasa, H., E. 2014. Menjadi Guru Profesional.Bandung:Rosda.

Newmark. Peter. 2013. A textbook of Translation. London: Shanghai Foreign Language Education Press.

Pratiwi, Icha., 2015. Improving Students Reading Comprehension Trough Listen-Read-Discuss (LRD) Strategy. Palembang: STIA Satya Negara.

Richards L., Jack., Renandya. A. Willy. 2010. Methodology in Language Teaching. New York: Cambridge University.

Rutherford, R., 2014: Statistical Model For Causal Analysis, New York: John Wiley and Sons Inc,.
Sugiyono. 2012. Metode Penelitian Kuantitatif Kualitatif dan R\&D. Bandung: Alfabeta.

Veit., Gould., and Clifford. In Icha Pratiwi . 2015. Improving Students Reading Comprehension Trough Listen-ReadDiscuss (LRD) Strategy. Palembang: STIA Satya Negara. 